\title{
Diet composition and provisioning rates of nestlings determine reproductive success in a subtropical seabird
}

\author{
Juliet S. Lamb ${ }^{1,2, *}$, Yvan G. Satgé ${ }^{1,2}$, Patrick G. R. Jodice ${ }^{1,3}$ \\ ${ }^{1}$ Department of Forestry and Environmental Conservation, ${ }^{2}$ South Carolina Cooperative Fish and Wildlife Research Unit, \\ and ${ }^{3}$ US Geological Survey South Carolina Cooperative Fish and Wildlife Research Unit, 260 Lehotsky Hall, Clemson \\ University, Clemson, SC 29634, USA
}

\begin{abstract}
Understanding how both quality and quantity of prey affect the population dynamics of marine predators is a crucial step toward predicting the effects of environmental perturbations on population-level processes. The Junk Food Hypothesis, which posits that energetic content of prey species may influence reproductive capacity of marine top predators regardless of prey availability, has been proposed as a mechanism by which changes in prey populations could affect predator populations in high latitude systems; however, support for this hypothesis has been inconsistent across studies, and further data are needed to elucidate variation in the relative importance of prey quantity and quality, both among predator species and across ecological systems. We tested the relative importance of prey quantity and quality to nestling survival in the eastern brown pelican Pelecanus occidentalis carolinensis across 9 breeding colonies in the northern Gulf of Mexico that varied in underlying availability of a key prey resource, the Gulf menhaden Brevoortia patronus. Both feeding frequency and meal mass were significantly correlated to energy provisioning rates and nestling survival, while energy density of meals had little effect on either metric. Compared to previous results from cold-water systems, we found lower and less variable energy densities $\left(4.4 \mathrm{~kJ} \mathrm{~g}^{-1}\right.$, vs. 5.2 to $6.5 \mathrm{~kJ} \mathrm{~g}^{-1}$ in other studies) and lipid content (9\% dry mass, vs. 16 to $23 \%$ in other studies) of common prey items. While Gulf menhaden was the most common prey species at all colonies, the proportion of menhaden fed to nestlings varied and was not strongly correlated to fledging success. We conclude that quantity rather than quality of prey, particularly small schooling fish, is the main driver of brown pelican reproductive success in this system, and that environmental perturbations affecting biomass, distribution, and abundance of forage fish could substantially affect brown pelican reproductive success.
\end{abstract}

KEY WORDS: Junk Food Hypothesis · Brown pelican · Energy density · Foraging · Gulf of Mexico

\section{INTRODUCTION}

Survival and reproductive success of apex predators in marine systems depends primarily on the production of sufficient food resources at lower trophic levels to meet the energetic requirements of both adults and young (Frederiksen et al. 2006). Both the

${ }^{*}$ Corresponding author: jslamb@clemson.edu quantity and quality of available prey can influence survival, reproduction, and ultimately population dynamics in apex predators; however, a switch to nutrient-poor prey may cause reduced fitness even if abundant prey is available (Rosen \& Trites 2000). This observation has given rise to the Junk Food Hypothesis (JFH), which posits that prey quality is

() The authors 2017. Open Access under Creative Commons by Attribution Licence. Use, distribution and reproduction are unrestricted. Authors and original publication must be credited. 
the ultimate driver of demographic parameters, regardless of availability (Österblom et al. 2008). Both experimental (Rosen \& Trites 2004, Romano et al. 2006) and field (Golet et al. 2000, Kadin et al. 2012, Cohen et al. 2014) studies have found that switching high-lipid prey for lower-energy alternatives can result in measurable reductions in breeding parameters, even when the amount and rate of delivery are unchanged. However, several other studies have suggested that prey availability and biomass have substantially greater effects on demographic parameters than varying energy densities (Trites \& Donnelly 2003, Jodice et al. 2006, Hjernquist \& Hjernquist 2010). Such inconsistencies in applicability of the JFH suggests that the relative influence of prey abundance and prey quality on the reproductive success of marine predators is both complex and context-dependent.

To date, studies assessing the JFH have been constrained to a relatively narrow geographic range comprising primarily high-latitude, cold-water systems (Österblom et al. 2008). Prey species in these systems are likely to have higher lipid reserves and greater energy densities on average than warmwater species (Stickney \& Torres 1989), which may reduce the range of energetic values in prey species available to top predators in tropical and subtropical regions compared to those observed at high latitudes. Energy density alone, however, may not accurately capture differences in prey quality. Optimal foraging theory (MacArthur \& Pianka 1966) takes into account not only the energy a predator obtains from prey, but also the energy it expends in finding, capturing, handling, and digesting prey. An optimal forager is expected to maximize the net energy gain, calculated as the difference between energy obtained from prey and energy expended in foraging. Thus, differences in prey behavior or distribution could result in variation in capture efficiency and net energy gain to predators from different prey types, even among prey species with similar energy content.

The relative importance of prey abundance and prey quality also depends on predator foraging strategies, which can differ both within and among predator species. Highly mobile marine predators employ a wide variety of foraging tactics, allowing them to exploit different prey types and forage in different sections of the water column (Ashmole 1971, Spear \& Ainley 1998, Ballance \& Pitman 1999). The plungediving brown pelican Pelecanus occidentalis employs a particularly distinctive high-volume foraging strategy, capturing large volumes of prey items simultaneously using a feeding method and jaw mor- phology more closely analogous to that of rorqual whales (Balaenopteridae) than that of other seabirds (Field et al. 2011). Variation in prey capture strategies can play an important role in prey selection for predators that transport food to stationary young (i.e. central-place foragers; Orians \& Pearson 1979). While single-prey loaders (individuals that capture and transport 1 prey item at a time) foraging optimally will act to maximize net energy delivery on an item-by-item basis (Bugge et al. 2011), a species such as the brown pelican that transports multiple prey items at once optimally seeks to maximize the energetic value of the entire prey load (Houston 1985). This logically results in a feeding strategy that prioritizes spatial aggregations of prey, even if individual prey items are of relatively low energetic value, as long as the net energy obtained is greater than the energy available from feeding on less-aggregated resources. Indeed, whales tend to specialize on lowerenergy prey than do cetacean species that pursue and capture individual prey items, prioritizing prey that can be captured in large volumes while minimizing energy expended in foraging (Spitz et al. 2012).

In the Gulf of Mexico, brown pelicans are one of the most highly visible and widely distributed inshore predator species, and thus represent a useful indicator species for assessing ecosystem dynamics at lower tropic levels (Shields 2014). Like many marine predators in the region, brown pelicans rely heavily on the abundant forage fish Gulf menhaden Brevoortia patronus as a food source (Ahrenholz 1991, Vaughan et al. 2007, Sagarese et al. 2016). While diet samples collected from the central northern Gulf indicate that Gulf menhaden constitute a high proportion of brown pelican diets (Arthur 1919), samples from the eastern portions of the species' Gulf range, where menhaden are naturally less abundant, show a decreasing trend in the predominance of menhaden consumed by pelicans (Fogarty et al. 1981). These data suggest that relative availability plays a role in the frequency of menhaden in pelican diets; however, it is unclear how or whether underlying variation in diet composition affects demographic parameters, nor how menhaden compares energetically to other available alternatives. Understanding the role of dietary variation in pelican demographics represents a crucial reference point for quantifying the effects of environmental stressors (e.g. Anderson et al. 1980, 1982), as well as providing important baseline information on ecological factors shaping trophic dynamics and predator distributions in the region.

We assessed the prey species composition, energy density, mass, nestling provisioning rate, and nest 
productivity of eastern brown pelicans $P$. o. carolinensis at 9 breeding colonies along natural gradients of Gulf menhaden availability in the eastern and western Gulf of Mexico. Based on predictions of the $\mathrm{JFH}$, we would hypothesize lower nest productivity at colonies with lower overall energy density of prey items, regardless of feeding rates or meal mass. Based on the predictions of the Nutritional Stress Hypothesis, we would hypothesize that all 3 factors contribute to nest productivity. Finally, a relationship between nest productivity and species composition of the diet without an accompanying difference in species-specific energy density would suggest that prey-specific factors other than energy content (e.g. behavior, accessibility) contribute to prey quality, supporting the idea that prey characteristics aside from energy density contribute to prey quality for top predators in this system.

\section{MATERIALS AND METHODS}

\section{Focal species and study area}

The brown pelican is a large-bodied nearshore seabird and one of only two species of pelican to inhabit marine environments year-round (Shields 2014). While raising young, pelicans feed mostly on fish by plunge-diving, and can transport large masses of fish in a single trip to provision nestlings (Field et al. 2011). Brown pelicans nest in offshore colonies that can number from hundreds to thousands of nests, where they lay up to 3 sequentially hatching eggs at $2 \mathrm{~d}$ intervals, incubate eggs for approximately $30 \mathrm{~d}$, and typically raise 1 to 2 young. Nestlings can fly at approximately $70 \mathrm{~d}$ and generally leave the colony area 70 to $90 \mathrm{~d}$ after hatch (Schreiber 1977). Brown pelicans exhibit biparental care and feeding throughout incubation and broodrearing, and feedings occur multiple times per day (Pinson \& Drummond 1993, Sachs \& Jodice 2009).

We focused on brown pelican breeding colonies within the range of Gulf menhaden, which extends along the northern Gulf coast from the Florida Panhandle in the east to the central Texas coast in the west (Fig. 1). Since the abundance of Gulf menhaden varies throughout the region, we selected sampling locations to represent the underlying range of prey availability. In Year 1 (2013), we sampled colonies from eastern, central, and western portions of the northern Gulf coast. In Years 2 and 3 (2014 and 2015), we focused on the western (Year 2) and eastern (Year 3) sections of the coast and sampled colonies both within and outside the core range of Gulf menhaden (Fig. 1). Gulf menhaden spawn in shallow offshore waters during winter (Christmas et al. 1982) and inhabit estuaries from February through October, with juveniles moving offshore into progressively deeper and more saline waters as they grow to adult size (Ahrenholz 1991). Juveniles are distributed primarily within the core menhaden range in the central northern Gulf, while adults range further to the east and west (Fig. 1).

\section{Diet composition and meal size}

In Year 1 (2013), we collected meals from chicks opportunistically (i.e. when handling chicks for banding). In Years 2 and 3 (2014 and 2015), we visited each study colony regularly (every 5 to $7 \mathrm{~d}$ ). To obtain meals from nestlings, we selected nests at which a nestling had been recently fed, based on either having seen a feeding occur or observing that the nestling had a visible bolus or engorged throat. We approached the nest from the colony edge and waited for the nestling to voluntarily regurgitate the meal, since nestling pelicans frequently employ regurgitation as a defense mechanism when disturbed. If the target nestling did not regurgitate, we selected a different nest and repeated the process until we had obtained approximately 10 complete, minimally digested meals. To limit disturbance to individual nests, we targeted different areas of the colony on subsequent visits; we also varied the time of day at which samples were collected. We collected meals throughout the chick-rearing period, from hatch (late April) through fledging (early August). To limit variation in chick age within each $1 \mathrm{~d}$ sample, we targeted nestlings at the same stage of feather development, indicating similar hatch dates, and recorded overall nestling age for the sample as estimated from feather growth (sensu Walter et al. 2013). We did not collect samples from recently hatched nestlings (1 wk old or less), both to limit disturbance and because pelican nestlings do not consume whole fish until several days after hatch (Sachs \& Jodice 2009). Additionally, since nestlings regurgitated food less readily as they reached adult size, we were not able to sample chicks older than approximately $10 \mathrm{wk}$ of age. Samples were collected in plastic bags and stored frozen until analysis.

In the laboratory, we thawed each sample in a warm-water bath, removed it from the plastic bag, dried off surface water using paper towels, then weighed $( \pm 0.01 \mathrm{~g})$, measured, and identified to spe- 


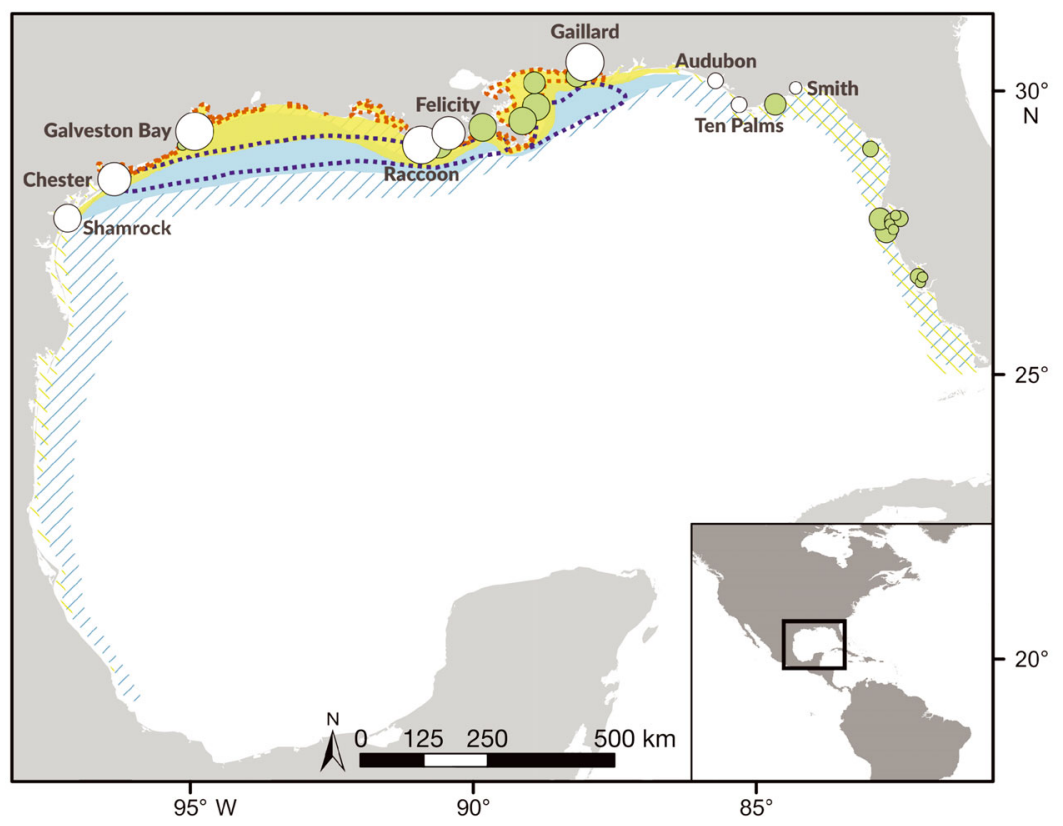

Fig. 1. Locations of eastern brown pelican Pelecanus occidentalis carolinensis colonies (white circles included in study; green circles not included) and Gulf menhaden Brevoortia patronus range in the northern Gulf of Mexico. Yellow and blue shading: summer and winter adult menhaden distributions, respectively (filled: major; hatched: minor); red and blue dashed line: major summer and winter egg/larvae distributions, respectively. Pelican colony marker sizes proportional to colony size during our study (75 to 5000 breeding pairs). Menhaden range data from Love et al. (2013)

cies each individual fish. Species identifications were based on descriptions in McEachran \& Fechhelm (2010). We also classified each fish as whole (no visible damage), partial-whole (total or standard length obtained, but some soft tissues missing), and partial (length could not be obtained). For samples containing large numbers (50 to 1000) of small fish of the same species ( $26 \%$ of samples), we counted the total number of individuals of the species, weighed and measured a subsample of 10 individual fish, and obtained a total weight and overall classification (whole, partial-whole, partial) for each species group. For samples containing extremely large numbers $(>1000)$ of small fish $(<1 \%$ of samples), we weighed and measured a subsample of 10 fish per species, weighed the overall sample, and used the average weight per fish to approximate the total number of fish in the sample. For samples in which individual fish were no longer intact, we counted the number of heads and tails present in the sample and used the larger of the 2 numbers as an approximate count. We did not analyze samples for which the digestive process was too advanced to identify fish to species.

Where needed, we corrected standard lengths of fish to total lengths using the best-fitting regression equation between standard and total length for that species calculated from whole samples (see Table S1 in the Supplement at www.int-res.com/ articles/suppl/m581p149_supp.pdf). To estimate the mass of partial-whole and partial fish, we calculated the length-weight relationship as the best-fitting regression equation between log total length and log mass of whole fish for each species by year (see Table S1 in the Supplement). For partial-whole fish (i.e. degraded fish for which we were able to measure length), we used the regression line to estimate the corrected mass of the whole fish from its length. For partial fish (i.e. degraded fish for which length was not measurable), we used the mean total length of whole and partial-whole individuals of the same species collected from the same breeding colony on the same day to estimate a corrected mass from the regression equation. Finally, we totaled the corrected masses of individual fish within each meal to obtain a total corrected meal mass.

\section{Meal delivery rate}

In Years 2 and 3 (2014 and 2015), to assess meal delivery rates, we conducted $3 \mathrm{~h}$ nest observations during each colony visit throughout the chick-rearing period (i.e. every 5 to $7 \mathrm{~d}$ from hatch through fledging, late April to early August). We selected groups of 15 to 20 nests, varying both the location within the colony and the time of day of observations between visits. During each $3 \mathrm{~h}$ period, we recorded all direct feedings in which a nestling's head entered an adult's throat and the nestling's throat was subsequently engorged. Indirect feedings (Sachs \& Jodice 2009) appeared to take place only within the first few days after hatch. Since chicks are brooded by adults during this time and are hidden from view, the frequency of such feedings is difficult to quantify; thus we excluded recently hatched nests from observation.

We calculated meal delivery rates on a per-nest basis. This measure reflects the rate of provisioning by adults, but not necessarily the rate at which each individual nestling consumes food. Since we were not able to consistently distinguish first-, second-, 
and third-hatched chicks in the field throughout the extended chick-rearing period and subsequently allocate feedings to individual chicks, we chose to assess delivery rates by nest with number of chicks as a covariate. We standardized delivery rates to a $15 \mathrm{~h}$ day, representing the average day length (civil twilight) during the study period. Pelicans are visual foragers and are considered not to forage at night (Shields 2014), and our observations also suggest that adult activity diminishes shortly after sunset.

\section{Energy density of meals}

We measured proximate composition and energy density of common prey species using methods as described by Anthony et al. (2000). Briefly, we dried fish to a stable mass in a $60^{\circ} \mathrm{C}$ oven $(3$ to $6 \mathrm{wk}$, depending on the size of the sample) and homogenized samples using a mortar and pestle. We then extracted lipids from the sample using a Soxhlet apparatus with a 7:2 (v:v) hexane:isopropyl alcohol solvent. Following the $10 \mathrm{~h}$ extraction, the sample was left to dry for $24 \mathrm{~h}$ and re-weighed to determine lean mass. We then extracted proteins from the sample by ashing at $600^{\circ} \mathrm{C}$ for $12 \mathrm{~h}$. The mass of the remaining skeletal ash was subtracted from the pre-ashing mass to determine the ash-free lean dry mass, which is composed primarily of proteins (94\%; Anthony et al. 2000). We then multiplied the lipid and protein contents by standard energetic values based on their relative assimilation efficiencies (lipids: $39.5 \mathrm{~kJ} \mathrm{~g}^{-1}$; proteins: $17.8 \mathrm{~kJ} \mathrm{~g}^{-1}$; SchmidtNielsen 1997) to obtain the overall energy density of the sample.

We measured energy densities in both regurgitated fish identified as whole during processing and diet items that could also be purchased as bait fish either live or freshly caught from fishing suppliers close to study colonies. For the 3 most common prey species (Gulf menhaden, Atlantic croaker Micropogonius undulatus, and pinfish Lagodon rhomboides), we conducted ANOVAs to determine whether energy content differed between sample types (bait fish vs. regurgitated fish) or regions. Because Gulf menhaden showed an apparent higher energy content in regurgitated fish than in bait samples $(\mathrm{p}=$ 0.056 ), we used only regurgitated samples to determine energy content for this species. In all other species, bait fish did not differ in energy content from regurgitated samples ( $p>0.1$ for each), and therefore we combined all samples within each region during further analysis. To account for regional variation, we calculated energy densities separately for the eastern and western Gulf where possible. We also tested for differences in energy density between locations within regions, and over time, in 2 species (Atlantic croaker and Gulf menhaden) and found that energetic content did not differ within regions $(p>0.1$ for each) and did not change as the season progressed ( $p>0.1$ for each). Therefore, we considered energy density of prey to be consistent throughout the breeding season and within each region. Since Gulf menhaden were the only prey species to show a bimodal size distribution, we measured energy content of juveniles $(<110 \mathrm{~mm}$ total length; Ahrenholz $1991)$ and adults $(>110 \mathrm{~mm})$ separately.

To determine meal-specific energy density, we multiplied the total mass of each prey species in the meal by the mean energetic value of that species. For species for which we did not measure energy density directly, we obtained energetic values for the same or closely related species from published literature (see Table S2 in the Supplement). Species for which we were able to directly measure energy content accounted for $93 \%$ of total biomass, while species for which we inferred values from closely related species measured directly $(4 \%)$ and values obtained from scientific literature $(3 \%)$ constituted the remaining $7 \%$. We then summed the energy derived from each individual species and divided by the total meal mass to obtain an energetic value $\left(\mathrm{kJ} \mathrm{g}^{-1}\right)$ for the full meal. We calculated meal-specific lipid content using the same process.

\section{Fledging success}

In Years 2 and 3 (2014 and 2015), we visited nesting colonies during late incubation and selected 3 to 4 groups of focal nests per colony, each group containing 20 to 30 nests. In colonies containing both elevated and ground nests, we selected closely spaced groups such that each contained nests of one type or the other to allow for comparison. On our initial visit, we recorded nest contents, assigned an identifying number to each nest, and photographed the nest group from marked observation points that could be accessed without disturbance to focal nests. On return visits, we identified nests using the numbered photograph and checked the contents of each nest from the observation point. Once nestlings reached 3 to 4 wk of age, concurrent with measurements and feather sampling, we banded nestlings on the right tarsus with a metal band (provided by USGS Bird Banding Laboratory, MD) and on the left tarsus 
with a permanent plastic band (Haggie Engraving, MD: 2014 green; 2015 blue) engraved with a unique 3-digit white alphanumeric code.

Once nestlings began to disperse away from nest locations (typically ca. $30 \mathrm{~d}$ post-hatch), we searched the surrounding areas of the colony with binoculars for banded chicks and recorded all bands observed. We conducted $3 \mathrm{~h}$ searches every 3 to $5 \mathrm{~d}$ until chicks reached $\geq 70 \mathrm{~d}$ of age. Beginning approximately $8 \mathrm{wk}$ after hatch, we also searched the colony every 3 to $5 \mathrm{~d}$ for banded chicks that had died, and recovered all bands found. To determine apparent fledging success (chicks per nest), nestlings that we observed alive at least $70 \mathrm{~d}$ after hatch, but subsequently were not observed at the colony or found dead, were presumed to have successfully fledged (Shields 2014). We calculated plot- and colony-wide fledge success as the number of chicks fledged from observation nests, divided by the total number of nests observed (i.e. apparent success). Since detectability of fledglings is high in this species and habitat, we considered this method to accurately represent overall fledging success.

\section{Statistical modeling}

To assess nutritional stress by colony, we compared values of meal mass $\left(\mathrm{g} \mathrm{meal}^{-1}\right)$, nest-specific provisioning rate (meals nest ${ }^{-1} \mathrm{~h}^{-1}$ ), and energy density of meals $\left(\mathrm{kJ} \mathrm{g}^{-1}\right)$ for each colony using ANOVAs with post-hoc Tukey's Honestly Significant Difference (HSD) tests. The product of these 3 components is the energy provisioning rate (EPR: $g$ nest $^{-1} \mathrm{~h}^{-1}$; Jodice et al. 2006). To obtain a combined measure of EPR by colony, we modeled energy-days for each colony, similarly to Jodice et al. (2006), by randomly selecting (with replacement) 100 values for provisioning rate (meals $\mathrm{d}^{-1}$ ) from the set of measured values. The model then chose at random (with replacement) a mass and an energetic value for each meal, multiplied meal mass by energy density to obtain total energy content per meal, and summed total energy across all meals for each modeled day to obtain a set of energy provisioning rates $\left(\mathrm{kJ} \mathrm{d}^{-1}\right)$. We calculated the mean and standard deviation of EPR for each colony by averaging values obtained from 1000 runs of the model. We chose to calculate EPR on a per-nest basis rather than a per-chick basis, to avoid the confounding relationship between higher provisioning rates and increased longevity of second- and thirdhatched chicks (Jodice et al. 2006). We then evaluated the relationships of individual provisioning met- rics to EPR using generalized linear models, and compared the relative and cumulative impacts of different parameters using ANOVAs on nested sequential linear models. Finally, to assess the relationship between species composition of the diet and rate of energy delivery to nestlings, we conducted non-metric multidimensional scaling (NMDS) on proportional composition of meals by species, and overlaid provisioning metrics on the resulting ordination.

\section{RESULTS}

\section{Diet composition}

Over 3 years, we collected 641 chick meals (Year 1: $\mathrm{N}=27$; Year 2: $\mathrm{N}=423$; Year 3: $\mathrm{N}=191$ ), totaling $98 \mathrm{~kg}$ of prey. We identified 46 prey species representing 25 families (Table 1). Thirty-six of the prey species represented $<1 \%$ each of biomass collected; of these, 16 species represented $<0.05 \%$ each of biomass collected (Table 1). Gulf menhaden was the most common prey species by weight overall ( $61 \%$ of biomass collected), as well as at each study site. The proportion of menhaden in total biomass varied by colony, with higher proportions of menhaden within the central Gulf (Fig. 2). Other common prey species did not show a pattern of abundance in meals across sites, except for anchovy Anchoa spp., which increased from the western to the eastern Gulf, and spot Leiostomus xanthurus which declined from the western to eastern Gulf (Fig. 3). The majority of meals $(76 \%)$ contained a single fish species, and the maximum number of species in a meal was 7 .

The overall proportion of menhaden in chick diets declined through the breeding season, (coefficient $=$ $\left.-0.34 \pm 0.10, F_{1,596}=12.3, \mathrm{p}<0.001\right)$, driven by a decrease in juvenile menhaden $<110 \mathrm{~mm}$ total length (coefficient $=-0.75 \pm 0.09, \mathrm{~F}_{1,596}=66.0, \mathrm{p}<0.001$ ). The proportions of adult menhaden, anchovies, and pinfish increased over the same period $(p<0.01$ for all). The remaining prey species showed no seasonal trends in proportional occurrence.

\section{Proximate composition and energy density}

Energetic content ranged from 3.3 to $5.5 \mathrm{~kJ} \mathrm{~g}^{-1}$ among all species with a mean \pm SD of $4.38 \pm 0.98 \mathrm{~kJ}$ $\mathrm{g}^{-1}$ wet mass (Fig. 4). Protein content had low variation across measured samples (CV $=8 \%)$ and correlated weakly with energy density per wet gram of 
fish $\left(F_{1,217}=22.3, \mathrm{p}<0.001, \mathrm{r}^{2}=0.09\right)$, while lipid content was variable both between and within species $(\mathrm{CV}=75 \%)$ and was highly correlated with energy density $\left(F_{1,217}=1929\right.$, $\left.\mathrm{p}<0.001, \mathrm{r}^{2}=0.90\right)$. First-year menhaden had significantly lower energy densities and lower lipid content than adult menhaden in both sampling regions (Fig. $4 ; \mathrm{p}<0.1$ for all).

\section{Meal mass, meal delivery rate, and energy density}

Average meal mass, meal delivery rate, and energy density of meals each differed significantly among colony sites (Fig. 5). The 2 biomass components of EPR, feeding frequency and meal mass, had similarly high levels of overall variation $(\mathrm{CV}$ frequency $=0.67$;

Table 1. Fish species occurring in the diets of eastern brown pelican Pelecanus occidentalis carolinensis chicks in the northern Gulf of Mexico, 2013 to $2015 .{ }^{*}<0.05 \%$ of total biomass

\begin{tabular}{|c|c|c|c|c|c|}
\hline Order & Family & Species & Common & Year & $\%$ Biomass \\
\hline Atheriniformes & Atherinidae & Menidia beryllina & Inland silverside & $1,2,3$ & 0.1 \\
\hline Aulopiformes & Synodontinae & Sybodus foetens & Inshore lizardfish & 1,2 & ${ }^{*}$ \\
\hline \multirow[t]{2}{*}{ Beloniformes } & Belonidae & Tylosurus crocodilus & Houndfish & 3 & $*$ \\
\hline & Hemiramphidae & Hemiramphus brasiliensis & Ballyhoo halfbeak & 1,2 & 0.1 \\
\hline \multirow[t]{6}{*}{ Clupeiformes } & Clupeidae & Brevoortia patronus & Gulf menhaden & $1,2,3$ & 61.0 \\
\hline & & Harengula jaguana & Scaled sardine & 1 & 0.3 \\
\hline & & Opisthonema oglinum & Atlantic threadfin herring & 2,3 & 1.7 \\
\hline & Engraulidae & Anchoa hepsetus & Striped anchovy & 2,3 & 1.5 \\
\hline & & Anchoa lyolepis & Dusky anchovy & 3 & 2.2 \\
\hline & & Anchoa mitchilli & Bay anchovy & $1,2,3$ & 7.5 \\
\hline \multirow[t]{2}{*}{ Cyprinodontiformes } & Cyprinodontidae & Cyprinodon variegatus & Sheepshead minnow & 2 & 0.2 \\
\hline & & Fundulus majalis & Striped killifish & 2 & ${ }^{*}$ \\
\hline Decapoda & Penaeidae & Farfantepenaeus duorarum & Pink shrimp & 2,3 & $*$ \\
\hline Mugiliformes & Mugilidae & Mugil cephalus & Striped mullet & 2,3 & 4.8 \\
\hline \multirow{26}{*}{ Perciformes } & Carangidae & Caranx crysos & Blue runner & 1 & 0.1 \\
\hline & & Chloroscombrus chrysurus & Atlantic bumper & $1,2,3$ & 0.6 \\
\hline & & Decapterus punctatus & Round scad & 3 & 0.1 \\
\hline & & Hemicaranx amblyrhynchus & Bluntnose jack & 2 & $*$ \\
\hline & & Selene setapinnis & Atlantic moonfish & 2 & * \\
\hline & Gobiidae & Gobioides broussonetii & Violet goby & 2 & * \\
\hline & Haemulidae & Orthopristis chrysoptera & Pigfish & 1,2 & $*$ \\
\hline & Lutjanidae & Lutjanus campechanus & Red snapper & 15 & 0.3 \\
\hline & Sciaenidae & Bairdiella chrysoura & Silver perch & 1,2 & 0.4 \\
\hline & & Cynoscion arenarius & Sand seatrout & 2,3 & 1.2 \\
\hline & & Cynoscion nebulosus & Spotted seatrout & 2,3 & 1.1 \\
\hline & & Larimus fasciatus & Banded drum & 2 & $*$ \\
\hline & & Leiostomus xanthurus & Spot & $1,2,3$ & 2.9 \\
\hline & & Menticirrhus americanus & Southern kingfish & 2 & 0.7 \\
\hline & & Micropogonias undulatus & Atlantic croaker & $1,2,3$ & 3.8 \\
\hline & & Sciaenops ocellata & Red drum & 2,3 & 0.5 \\
\hline & Scombridae & Auxis thazard & Frigate mackerel & 3 & 0.2 \\
\hline & & Scomberomorus cavalla & King mackerel & 2 & 0.1 \\
\hline & & Scomberomorus maculatus & Spanish mackerel & 2 & 0.3 \\
\hline & Serranicae & Diplectrum formosun & Sand perch & 3 & 0.2 \\
\hline & Sparidae & Calamus proridens & Littlehead porgy & 1 & $*$ \\
\hline & & Lagodon rhomboides & Pinfish & $1,2,3$ & 2.4 \\
\hline & & Stenotomus caprinus & Longspine porgy & 1 & $*$ \\
\hline & Stromateidae & Peprilus burti & Gulf butterfish & 2,3 & 0.1 \\
\hline & & Peprilus paru & American harvestfish & 2 & 0.1 \\
\hline & Trichiuridae & Trichiurus lepturus & Atlantic cutlassfish & $1,2,3$ & 3.6 \\
\hline \multirow[t]{2}{*}{ Pleuronectiformes } & Cynoglossidae & Symphurus urospilus & Spottail tonguefish & 3 & 0.1 \\
\hline & Paralichthyidae & Citharichthys spilopterus & Bay whiff & 2,3 & 0.1 \\
\hline Scorpaeniformes & Triglidae & Prionotus tribulus & Bighead searobin & 2,3 & $*$ \\
\hline Siluriformes & Ariidea & Bagre marinus & Gafftopsail catfish & $1,2,3$ & 0.3 \\
\hline Tetraodontiformes & Diodontidae & Diodon holocanthus & Longspine porcupinefish & 2 & $*$ \\
\hline Teuthida & Loliginidae & Lolligunculla brevis & Atlantic brief squid & 1,3 & * \\
\hline \multirow{3}{*}{ Other } & & & Isopod & 3 & * \\
\hline & & & Bait (chicken) & 3 & $*$ \\
\hline & & & Unknown & & 1.2 \\
\hline
\end{tabular}




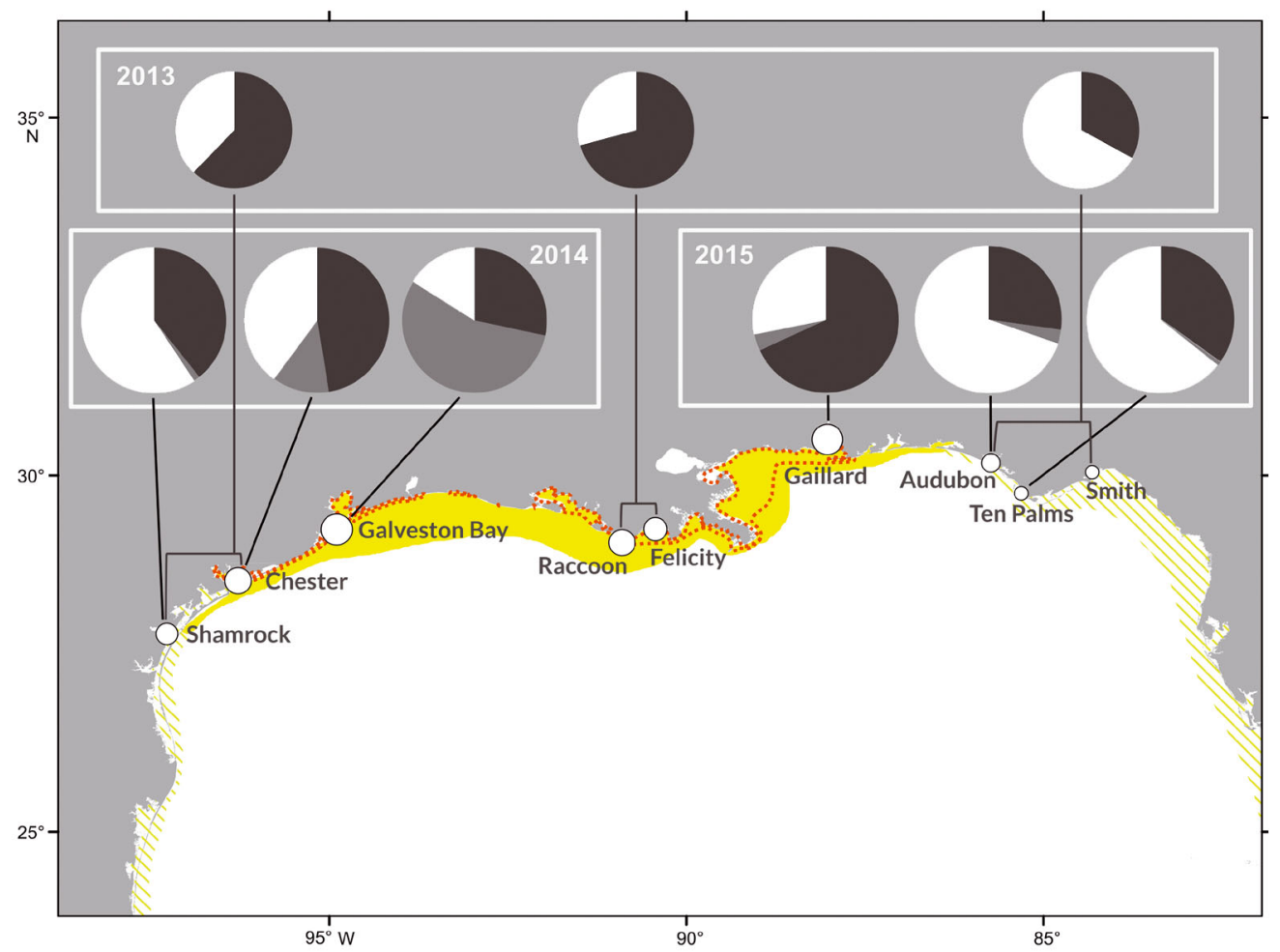

Fig. 2. Percentage of Gulf menhaden Brevoortia patronus in eastern brown pelican Pelecanus occidentalis carolinensis chick diets in the northern Gulf of Mexico, 2013 to 2015. Pies represent the portion by biomass of adult menhaden (dark grey), firstyear menhaden (light grey) and other prey species (white) in chick diets. Yellow shaded areas: summer distributions of adult (solid: major; hatched: minor) and first-year (red dashed outline) menhaden (Love et al. 2013)

CV mass $=0.76$ ), while energy density of meals was less variable $(\mathrm{CV}=$ 0.10). Relative to regional averages, individual colony sites showed a generally opposing pattern between meal mass and meal delivery rates (Fig. 6a). Colonies with below-average meal delivery rates tended to have above-average meal masses, and conversely. Energy densities followed a similar pattern to meal masses, but did not deviate more than $10 \%$ from the overall mean. Site-specific variation in all 3 provisioning metrics tended to covary (Fig. 6b), with below-average variability toward the central and eastern Gulf and higher variability in the west.

Provisioning metrics also varied seasonally within the chick-rearing period. Both meal mass and energy density increased over the course of the breeding season (meal mass: coefficient $=2.48 \pm 0.24, F_{1,596}=104$ ，
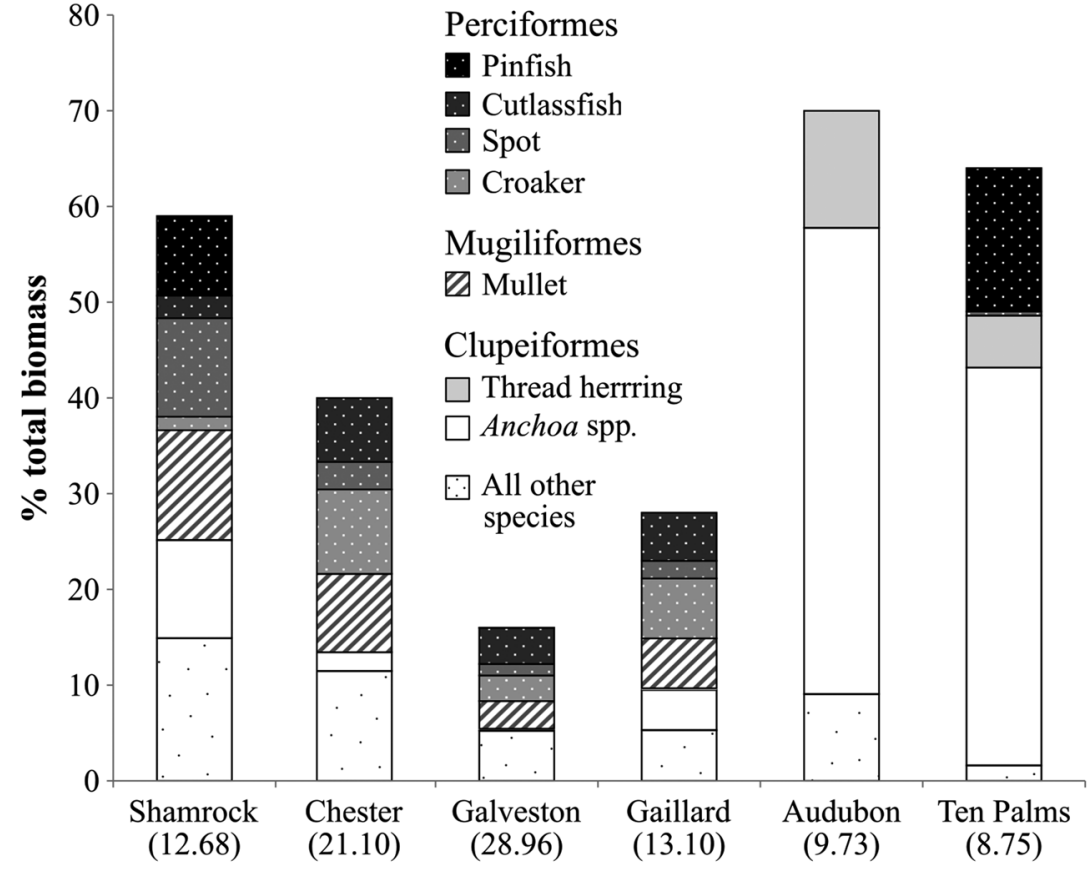

Fig. 3. Proportion of biomass of eastern brown pelican Pelecanus occidentalis carolinensis nestling diets in the northern Gulf of Mexico represented by all prey species other than Gulf menhaden Brevoortia patronus, 2014 to 2015. Species comprising $<1 \%$ overall prey biomass are grouped. Parentheses: sample sizes (mass of recovered meals, $\mathrm{kg}$ ) for each colony 


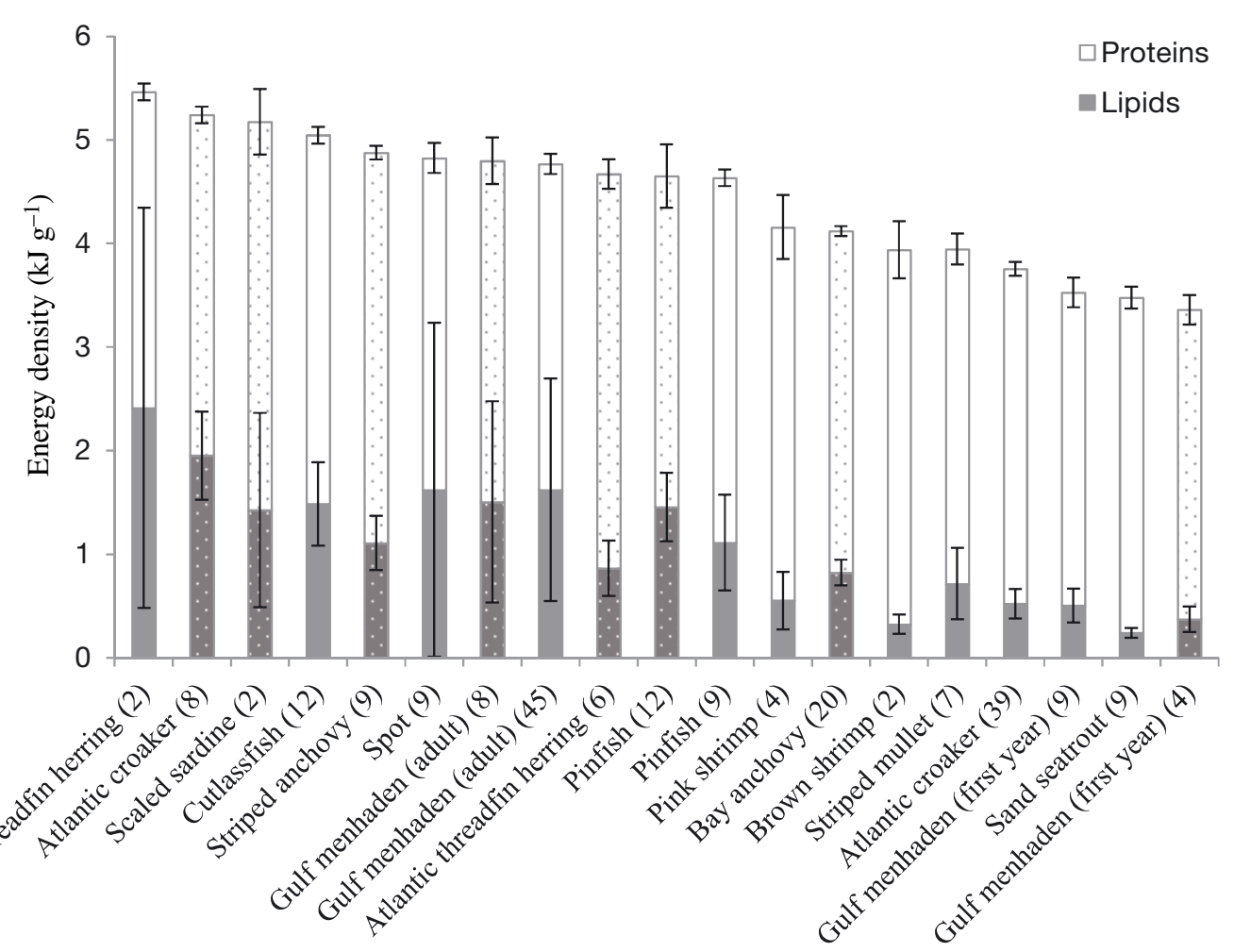

Fig. 4. Mean energy densities of common (each $>1 \%$ of total biomass) eastern brown pelican Pelecanus occidentalis carolinensis prey items collected from the northwestern (Corpus Christi Bay to Galveston Bay, TX: solid bars) and northeastern Gulf of Mexico (Mobile Bay, AL to Apalachee Bay, FL: stippled bars), 2014 to 2015. Error bars: 95 \% CI. Parentheses: sample sizes

$\mathrm{p}<0.001$; energy density: coefficient $=0.007 \pm 0.001$, $\left.F_{1,596}=29.5, \mathrm{p}<0.001\right)$, while meal delivery rate decreased during the same period (coefficient $=$ $\left.-0.036 \pm 0.005, F_{1,135}=46.1, \mathrm{p}<0.001\right)$. However, rates of energy delivery, calculated as the product of daily average meal mass, energy density, and meal delivery rates, neither increased nor decreased during the breeding season $\left(F_{1,40}=0.60, \mathrm{p}>0.20\right)$.

\section{Biomass and energy provisioning rates}

Mean biomass provisioning rate (BPR) varied by colony from $454 \pm 294$ to $1106 \pm 587 \mathrm{~g} \mathrm{~d}^{-1}$. Mean energy provisioning rate (EPR) varied by colony from 1977 to $4876 \mathrm{~kJ} \mathrm{~d}^{-1}$ (Table 2). BPR and EPR were highly correlated (coefficient $=4.48 \pm 0.34, F_{1,5}=$ 168.0, $\mathrm{p}<0.001$ ). Of the individual provisioning covariates measured at each colony, meal delivery rate explained $38 \%$ of variance in energy provisioning rate, followed by meal mass $(24 \%)$ and energy density of meals $(1 \%)$. Both feeding frequency and meal mass improved model fit when added sequentially to the intercept-only model, but adding energy density did not significantly improve the fit of the model (Table 3).

Meal delivery rates increased with increasing proportions of menhaden and anchovy, which were also associated with decreasing energy density of meals (Fig. $7 \mathrm{a}, \mathrm{b}, \mathrm{c})$. By comparison, meals containing higher proportions of spot, croaker, and pinfish were associated with lower delivery rates and higher energy densities (Fig. 7a,b,c). Meal masses were highest for meals containing striped mullet Mugil cephalus or Atlantic cutlassfish Trichiurus lepturus and lowest for meals containing anchovies (Fig. 7b). The proportion of biomass represented by small size-class fish ( $<110 \mathrm{~mm}$ total length) at individual colonies correlated to feeding frequency $\left(F_{1,5}=7.18, \mathrm{p}=0.04, \mathrm{r}^{2}=\right.$ 0.59 , coefficient $=0.108 \pm 0.04$ ) but not to meal mass or energy density $\left(F_{1,5}=1.82, \mathrm{p}>0.20\right.$ for both).

\section{Fledging success}

Average fledging success (chicks per nest) was strongly correlated to both mean energy provisioning rate and biomass provisioning rate at the colony level 

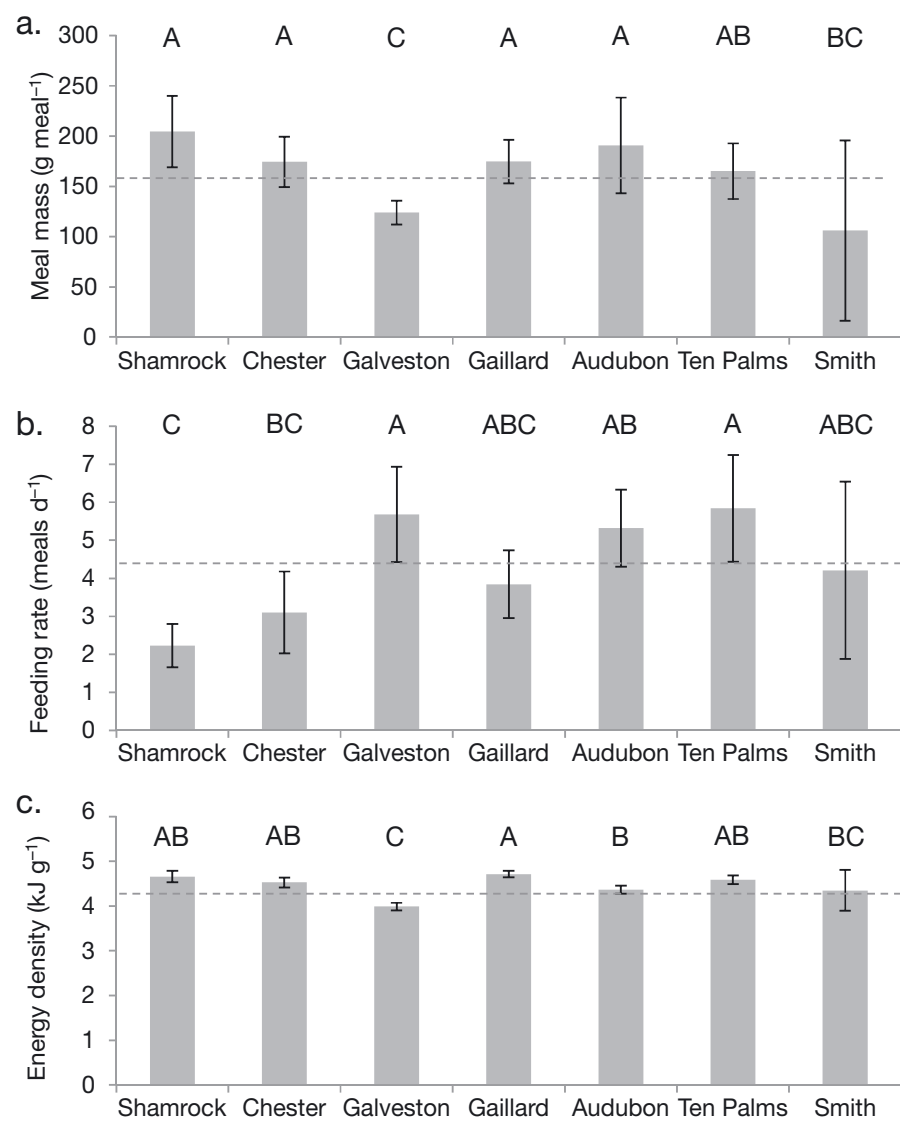

Fig. 5. Comparison of average (a) meal mass, (b) provisioning rate, and (c) energy density of meals between eastern brown pelican Pelecanus occidentalis carolinensis colony sites, northern Gulf of Mexico, 2014 to 2015. Letters above bars: Tukey post-hoc groups; error bars: $95 \%$ CI of means; dashed lines: global mean values

(Fig. 8). Of the individual components of EPR, feeding frequency explained the largest portion of variance in nest productivity $(49 \%)$, followed by meal mass $(15 \%)$ and energy density of meals $(0.1 \%)$. Both feeding frequency and meal mass significantly improved the fit of a null model for average fledging success by colony, while energy density did not improve model fit (Table 3). Diet composition (\% menhaden $)$ did not correlate with fledging success $\left(F_{1,5}=\right.$ $0.89_{i} \mathrm{p}>0.20$ ).

\section{DISCUSSION}

We found that, in comparison to seabirds at high latitudes, brown pelicans in the Gulf of Mexico experience a narrow range of variation in energy content between prey species. Furthermore, our results suggest that nest productivity of brown pelicans is more

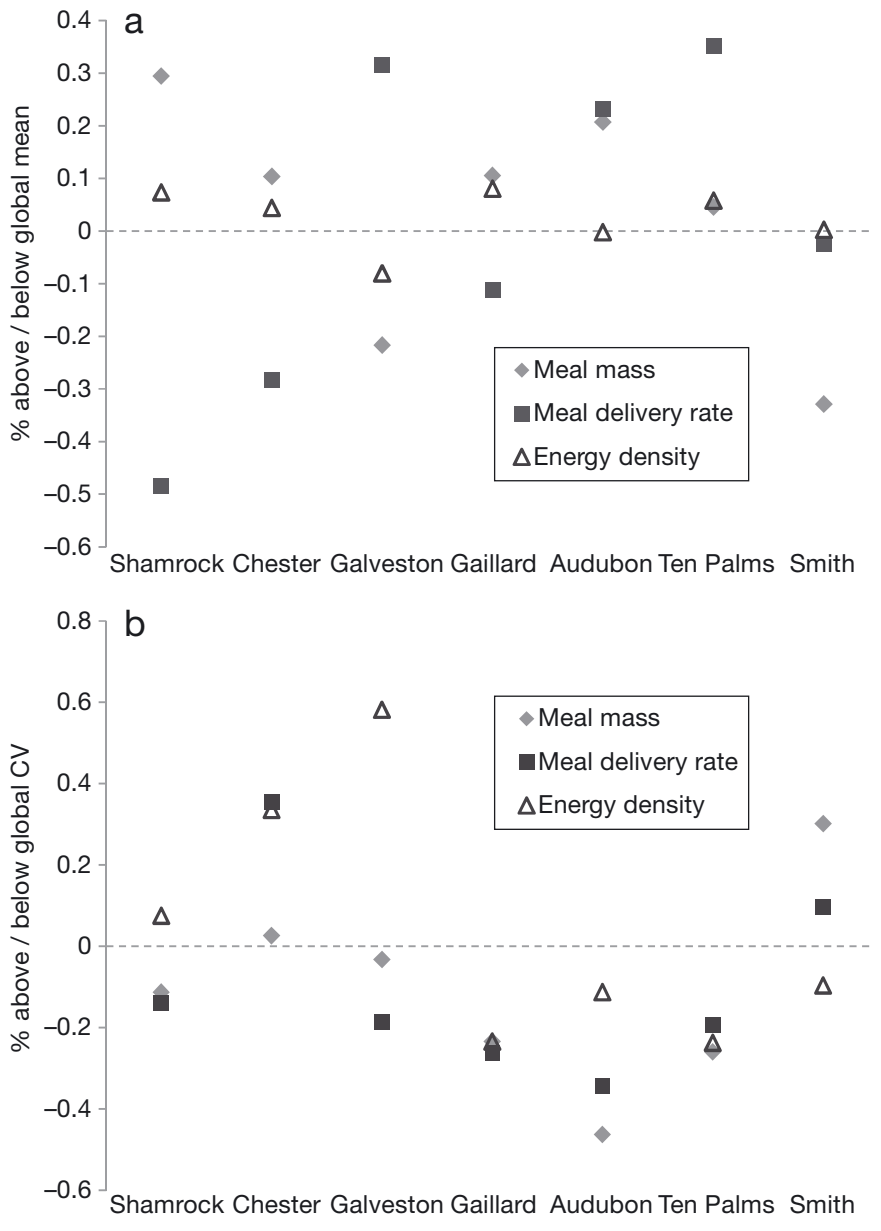

Fig. 6. Drivers of between-colony variation in (a) mean values of provisioning metrics and (b) coefficients of variation for eastern brown pelican Pelecanus occidentalis carolinensis colonies in the northern Gulf of Mexico, 2014 to 2015. The mean value for each metric across all samples is set at zero, and individual points represent deviation from the global mean (as a percentage of global mean) at that colony site

closely associated with feeding frequency, followed by meal mass, and that species composition and energy content of meals have little effect on productivity. Taken together, these results suggest that brown pelicans provisioning nestlings in this system employ a feeding strategy that prioritizes frequent deliveries of highly available prey regardless of energy density. While our results indicate that the JFH may not be useful for explaining the relationship between nestling provisioning and nest productivity in this system, our study also highlights the key importance of small, highly abundant schooling fish for breeding brown pelicans in the Gulf of Mexico.

Although brown pelicans delivered a wide variety of prey species to nestlings, both lipid content and 
Table 2. Mean values $( \pm$ SD) for eastern brown pelican Pelecanus occidentalis carolinensis nest productivity (fledged chicks per nest) and energy provisioning metrics by colony in the northern Gulf of Mexico, 2014 to 2015. BPR, EPR: biomass and energy provisioning rates, respectively

\begin{tabular}{|c|c|c|c|c|c|c|c|}
\hline & Colony & Productivity & $\begin{array}{l}\text { Provisioning rate } \\
\qquad\left(\text { meals d }^{-1}\right)\end{array}$ & $\begin{array}{l}\text { Meal mass } \\
\text { (g per meal) }\end{array}$ & $\begin{array}{l}\text { Energy } \\
\left(\mathrm{kJ} \mathrm{g}^{-1}\right)\end{array}$ & $\begin{array}{c}\mathrm{BPR} \\
\left(\mathrm{g} \mathrm{d}^{-1}\right)\end{array}$ & $\begin{array}{c}\mathrm{EPR} \\
\left(\mathrm{kJ} \mathrm{d}^{-1}\right)\end{array}$ \\
\hline 2014 & Shamrock & $0.51 \pm 0.66$ & $2.23 \pm 1.28$ & $205 \pm 138$ & $4.66 \pm 0.50$ & $552 \pm 345$ & $2574 \pm 1618$ \\
\hline 2014 & Chester & $0.68 \pm 0.79$ & $3.10 \pm 2.80$ & $174 \pm 136$ & $4.53 \pm 0.61$ & $644 \pm 559$ & $2902 \pm 2548$ \\
\hline 2014 & Galveston & $0.94 \pm 0.86$ & $5.68 \pm 3.08$ & $124 \pm 91$ & $3.99 \pm 0.63$ & $749 \pm 446$ & $2995 \pm 1804$ \\
\hline 2015 & Gaillard & $1.06 \pm 0.85$ & $3.84 \pm 1.89$ & $175 \pm 102$ & $4.69 \pm 0.36$ & $758 \pm 408$ & $3451 \pm 1879$ \\
\hline 2015 & Audubon & $1.42 \pm 0.85$ & $5.32 \pm 2.33$ & $191 \pm 170$ & $4.33 \pm 0.38$ & $1106 \pm 587$ & $4793 \pm 2554$ \\
\hline 2015 & Ten Palms & $1.64 \pm 0.95$ & $5.84 \pm 3.14$ & $168 \pm 105$ & $4.59 \pm 0.35$ & $1042 \pm 586$ & $4876 \pm 2722$ \\
\hline 2015 & Smith & $0.30 \pm 0.64$ & $4.21 \pm 3.08$ & $106 \pm 78$ & $4.35 \pm 0.39$ & $454 \pm 294$ & $1977 \pm 1286$ \\
\hline
\end{tabular}

Table 3. ANOVA comparisons of nested models for colony-specific mean eastern brown pelican Pelecanus occidentalis carolinensis nestling energy provisioning rates and nest productivity based on feeding rate, meal mass, and energy density of meals, northern Gulf of Mexico, 2014 to 2015. Terms are added sequentially, and a p-value of <0.05 indicates a significant improvement in fit compared to the previous model

\begin{tabular}{|c|c|c|c|c|c|c|}
\hline Terms & Residual df & Residual deviance & df & Deviance & $F$ & $\mathrm{p}$ \\
\hline \multicolumn{7}{|c|}{ Energy provisioning rate } \\
\hline Intercept only & 6 & 7236805 & & & & \\
\hline+ feeding rate & 5 & 4498564 & 1,5 & 2738240 & 24.79 & 0.016 \\
\hline+ meal mass & 4 & 379699 & 1,5 & 4118866 & 37.3 & 0.009 \\
\hline + energy density & 3 & 331316 & 1,5 & 48383 & 0.44 & 0.56 \\
\hline \multicolumn{7}{|l|}{ Nest productivity } \\
\hline Intercept only & 6 & 1.397 & 1,5 & & & \\
\hline+ feeding rate & 5 & 0.714 & 1,5 & 0.683 & 47.83 & 0.006 \\
\hline+ meal mass & 4 & 0.056 & 1,5 & 0.658 & 46.12 & 0.007 \\
\hline + energy density & 3 & 0.043 & 1,5 & 0.896 & 0.90 & 0.41 \\
\hline
\end{tabular}

overall energetic value of prey items in nestling diets varied within a narrow range. Compared to results from previous work in temperate and subpolar systems, average energetic content of prey species in our study was 15 to $30 \%$ lower, with 55 to $78 \%$ less variation between species (Fig. 9). Our observations accord with previous work on mesopelagic fish species in the Gulf of Mexico (Stickney \& Torres 1989) and the South Atlantic Bight (Jodice et al. 2011), which suggests that fish species in the tropical north-
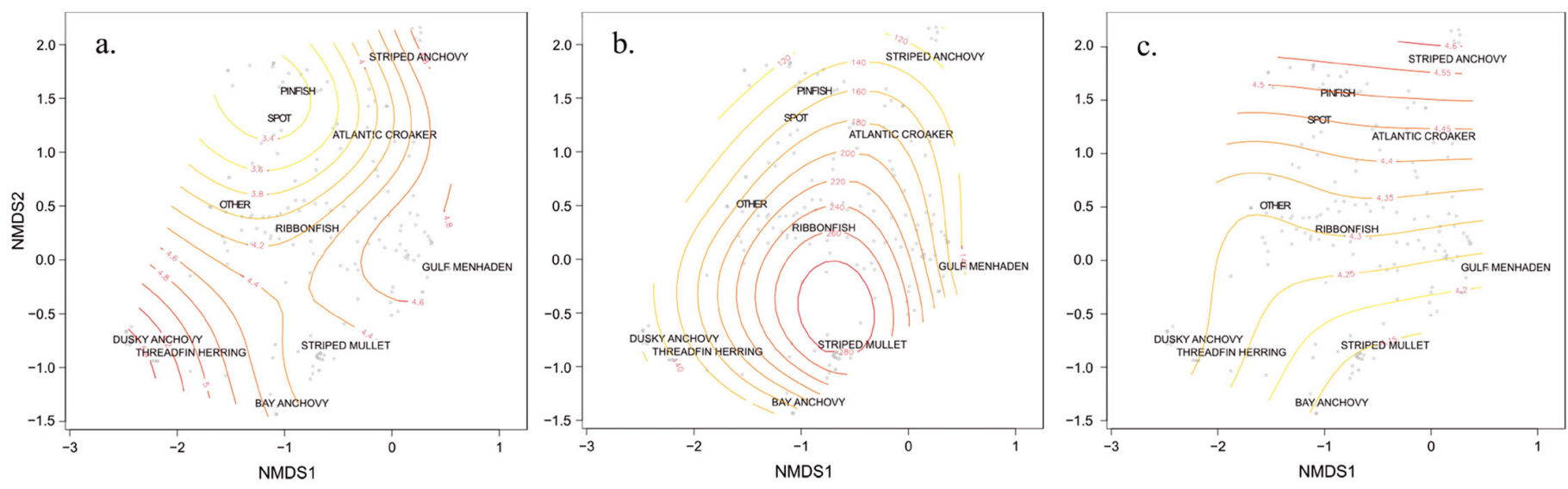

Fig. 7. Non-metric multidimensional scaling plots showing the distribution of species composition of individual meals (grey dots) collected from eastern brown pelican Pelecanus occidentalis carolinensis nestlings in the northern Gulf of Mexico, 2014 to 2015. Surface plots of the 3 components of energy provisioning rate are overlaid to show isoclines; warmer colors represent direction of increase in ordination space. (a) Meal delivery rate, (b) mass, and (c) energy density 

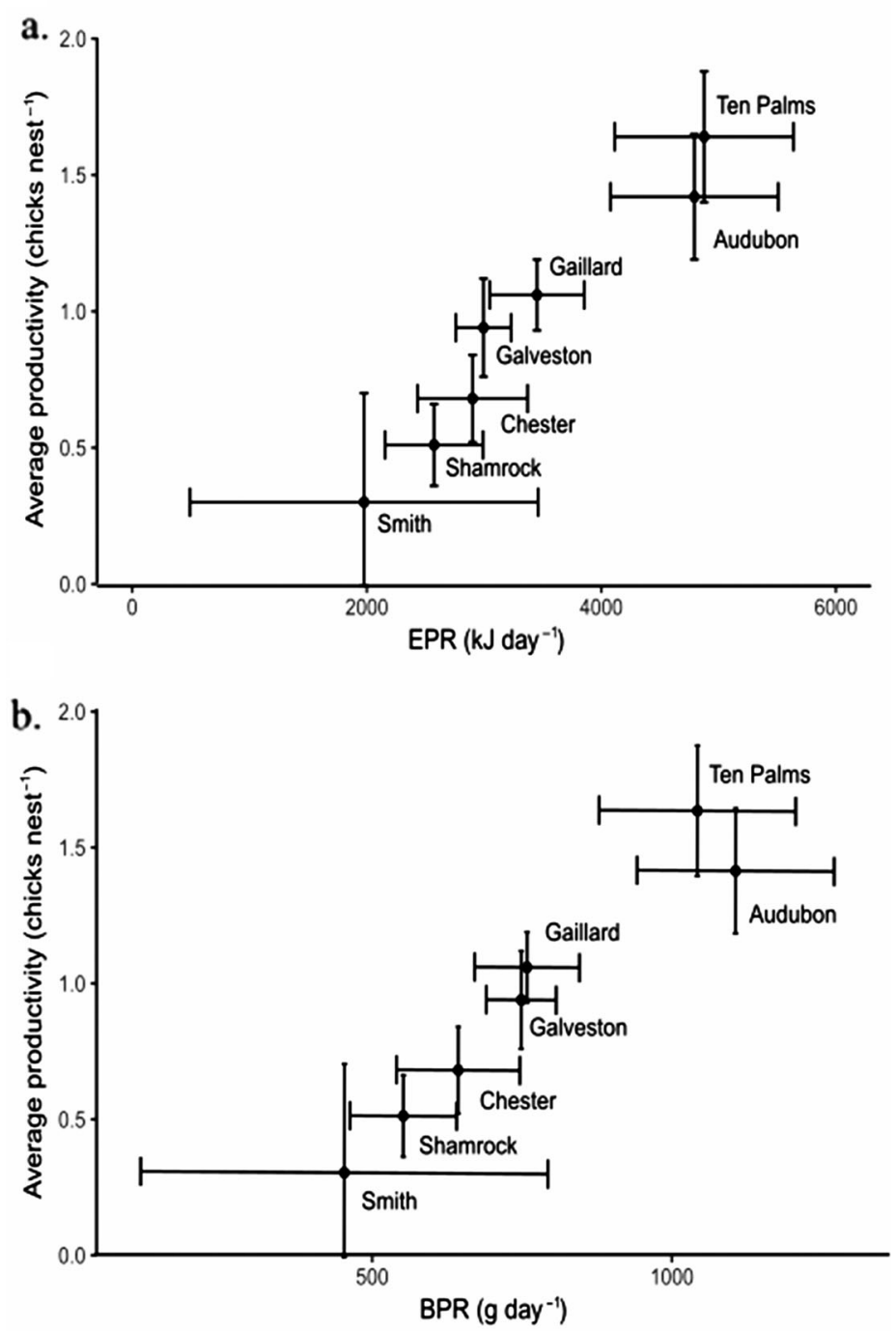

Fig. 8. Linear relationship between (a) energy provisioning rate $(\mathrm{EPR})$ and nest productivity $\left(y=0.0004 x-0.508 ; \mathrm{r}^{2}=\right.$ 0.952 ), and (b) biomass provisioning rate (BPR) and nest productivity $\left(y=0.0019 x-0.535 ; r^{2}=0.943\right)$ at eastern brown pelican Pelecanus occidentalis carolinensis nesting colonies in the northern Gulf of Mexico, 2014 to 2015. Error bars: $95 \% \mathrm{CI}$ of means

west Atlantic have relatively higher protein levels, lower lipid reserves, and lower overall energetic values than species at northern and southern latitudes characterized by cooler oceanic temperatures and higher inter-seasonal variability. Despite the wide longitudinal variation of our sampling area and the variation in prey species composition relative to prey distribution, energetic content of meals fed to pelican chicks varied little between colonies. As a result, colony-specific energy provisioning rates closely reflected a combination of meal mass and frequency of meal deliveries (i.e. BPR), but did not relate to energy content of meals. Our results suggest that prey energy content is not a significant driver of energy delivery rates to nestlings for brown pelicans in this system, given the lack of variation in energy density between prey species.

Our results support previous observations of the predominance of Gulf menhaden in brown pelican diets (e.g. Arthur 1919, Fogarty et al. 1981); however, the proportions of menhaden consumed by pelicans in our study varied both spatially and temporally depending on underlying distribution and inferred availability. The proportion of juvenile menhaden in nestling diets declined over the course of the chickrearing period, during which young-of-the year menhaden move gradually from shallow estuarine waters to offshore habitats, decreasing their availability to foraging pelicans (Ahrenholz 1991). Other prey, including pinfish, anchovy, and adult menhaden, increased proportionally during the same period, and overall rates of energy delivery to nestlings remained consistent throughout the breeding season. Gulf menhaden constituted 60 to $84 \%$ of pelican nestling diets in colonies at the core of its range (i.e. the central northern Gulf of Mexico), but $<40 \%$ of diets in colonies at the eastern and western margins of its range. Notably, first-year menhaden (individuals hatched during the previous winter) represented $56 \%$ of nestling pelican diets at the colony closest to the core of their range and $3 \%$ or less outside the range margins. As the proportion of menhaden in nestling diets declined, other prey species, principally anchovy in the eastern Gulf and spot, croaker, and pinfish in the western Gulf, contributed more significantly to nestling diets. The comparatively larger size of pelican breeding colonies at the core of the Gulf menhaden range than at its margins may indicate that areas with high menhaden availability can support larger aggregations of breeding pelicans. However, further study is required to distinguish the effects of inter-regional variation in prey availability on population size from those of conservation history (e.g. King et al. 1985, Wilkinson et al. 1994) and breeding habitat availability (e.g. Walter et al. 2013).

We tested the effects of prey energy content on demographic rates by relating inter-colony variation in reproductive success to nutritional parameters. We found that the rate of biomass delivery alone explained $>90 \%$ of variation in nest productivity between sites, with a feeding rate of approximately $800 \mathrm{~g} \mathrm{~d}^{-1}$ (ca. $56000 \mathrm{~g}$ total from hatch through fledging) required to successfully fledge 1 nestling. Despite variation in prey composition, energy density of meals varied little between colony sites and thus did not contribute to variation in fledging rates. The lack 
a.

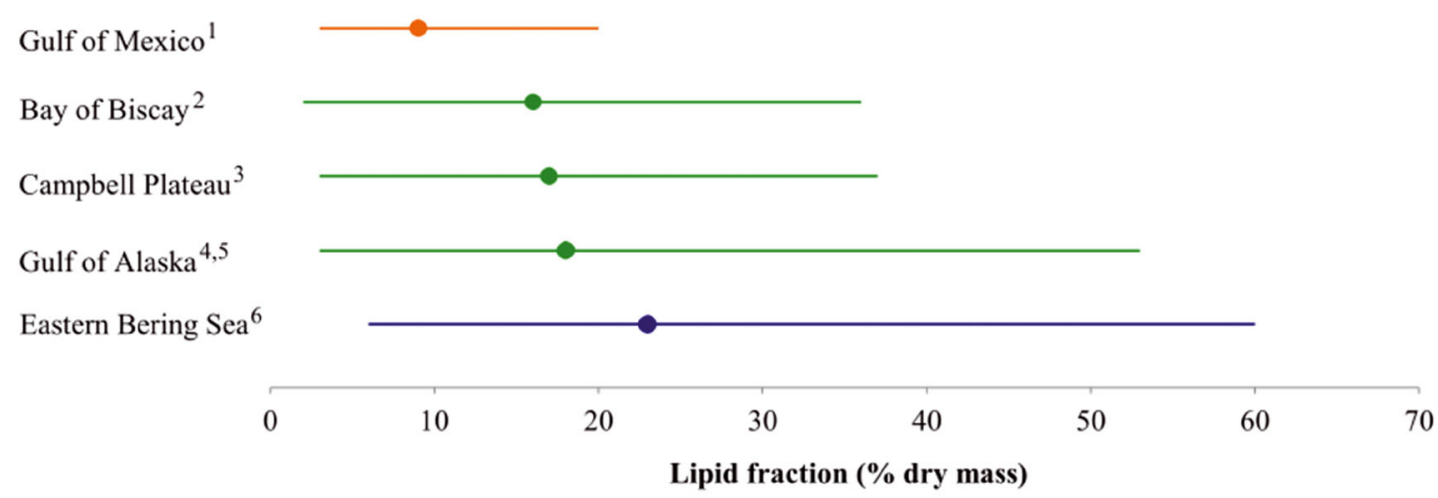

b.

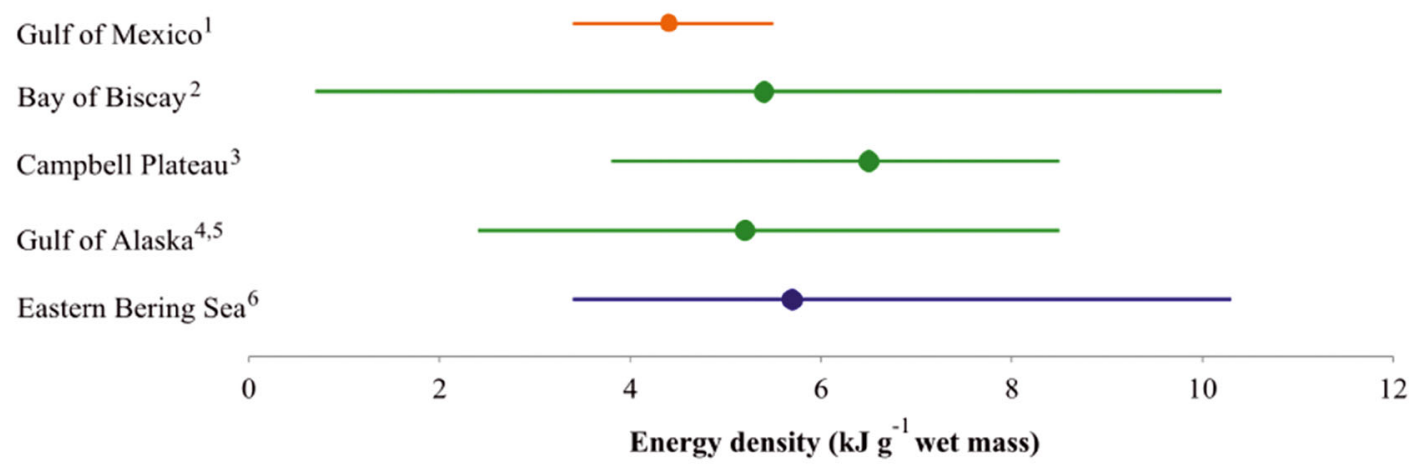

Fig. 9. Comparison of (a) lipid content and (b) energy density of forage fish in this study (mean and range) with published values from other regions. Colors indicate marine regions (orange: tropical; green: temperate; blue: subpolar). Data sources 1: this study; 2: Spitz et al. (2010); 3: Meynier et al. (2008); 4: Anthony et al. (2000); 5: Van Pelt et al. (1997); 6: Payne et al. (1999)

of relationship between energy density of meals and nestling survival indicates that the JFH may not be relevant in this context. While support for the JFH to date has come from cold-water systems at high latitudes (Österblom et al. 2008), our results suggest that prey communities in the subtropical northern Gulf of Mexico present top predators with a narrow range of energetic options, which may contribute to a lack of transferability of the JFH to warm-water systems. However, several previous studies in high-latitude systems have also found biomass provisioning metrics to be considerably better predictors of fledging success than energetic content of food items (e.g. Jodice et al. 2006, Hjernquist \& Hjernquist 2010). Österblom et al. (2008) suggest that the negative influence of lower-energy food items is particularly pronounced in certain species of seabirds, especially species specialized to carry single prey items or small masses of prey, species with energetically expensive foraging strategies, and species with low digestive efficiency. Although plunge-diving is energetically demanding (Green et al. 2009), pelicans are able to capture and carry large volumes of prey, which may allow them to buffer the effects of reduced prey quality by increasing prey quantity with minimal increases in foraging effort.

It is interesting to note the apparently opposing relationship between meal delivery rates and meal mass, the 2 primary drivers of nest productivity. In general, as meal delivery rates increased, meal masses decreased on a colony-wide basis. The relative magnitude of variation in these 2 metrics provides a useful basis for assessing how foraging conditions and strategies differ from site to site, indicating that there may be a trade-off between prey load maximization and time spent foraging. We found that differences in prey species composition helped to explain the negative relationship between meal mass and provisioning rates. Across species comprising $>1 \%$ of nestling diets, higher percentages of schooling fish of the order Clupeiformes (menhaden, Atlantic threadfin herring Opisthonema oglinum, and anchovies) were related to higher provisioning rates and generally lower meal masses, while spot, croaker, and pinfish (order Perciformes), as well as striped mullet (Mugiliformes), corresponded to lower 
feeding rates and higher meal masses. Clupeiformes are typically schooling fish that occur in large aggregations in clear and relatively shallow water, while the remaining species are bottom-dwellers that do not school and avoid waters where visibility is high (Nelson 1994). For a multiple-prey loader that can capture several prey items at once, targeting highly concentrated prey resources regardless of energetic content could be a means of maximizing biomass delivery.

Overall, we found that higher meal delivery rates were driven by the proportion of diet biomass composed of fish $<110 \mathrm{~mm}$ total length, regardless of species. Despite being among the least energy-rich prey items observed, juvenile menhaden constituted $>50 \%$ of pelican diets at the core of their range, suggesting that pelicans target accessible and highly aggregated prey without regard for energetic content. The importance of small, abundant schooling fish to brown pelican reproductive output is of potential conservation interest. Recruitment rates in Gulf menhaden are highly sensitive to temperature and precipitation, with warmer and wetter winters producing comparatively fewer recruits in the next year class (Deegan 1990). Given that winter temperatures and precipitation are expected to rise under current climate change projections (Biasutti et al. 2012), the availability of larval fish (e.g. Muhling et al. 2011) could become more limited or more variable in future climactic conditions. Additionally, pollution events can significantly depress survival of larval fish (Incardona et al. 2014) and could have indirect effects on prey dynamics that compound the direct effects of pollutant exposure to predators.

\section{CONCLUSIONS}

Our study suggests that, in the nearshore waters of the northern Gulf of Mexico, energetic content of prey does not vary sufficiently for differences in species composition to directly impact demographic rates of pelicans via energy provisioning, as posited by the JFH. Since previous studies of the effects of prey quality and quantity on the demographics of marine top predators have occurred primarily in cold-water, high-latitude systems, our work fills a gap in existing data, and suggests that the JFH may not readily apply to warm-water systems. We found a strong correspondence between biomass provisioning rates and nest productivity, suggesting that the amount, rather than the type, of food delivered to brown pelican nestlings predicts their survival to fledging. Our study also reveals a positive association of small schooling fish with high biomass delivery rates, and thus nest productivity, suggesting that availability of highly abundant schooling forage fish, particularly Gulf menhaden, is a key component of brown pelican reproductive success. Finally, our results indicate that an understanding of comparative prey quality that incorporates behavior, accessibility, and spatial distribution of prey, in the context of predator foraging behavior, has greater power than prey energy content alone to explain the relationship between diet composition and demography of marine predators.

Data archive. The data used in this study are publicly available in the US Geological Survey Science Data Catalog (https://doi.org/10.5066/F7R78D6J).

Acknowledgements. This work was supported by the US Department of the Interior, Bureau of Ocean Energy Management, Environmental Studies Program, Washington, DC, through Inter-Agency Agreement Number M12PG00014 with the US Geological Survey. All laboratory work took place at Clemson University facilities. Field research was conducted with permission from the Clemson University Animal Care and Use Committee (2013-026). Permits for field data collection were provided by the US Geological Survey Bird Banding Laboratory (22408), Texas Parks and Wildlife (SPR-0113-005), Audubon Texas, The Texas Nature Conservancy, Louisiana Department of Wildlife and Fisheries (LNHP-13-058 and LNHP-14-045), and the Florida Fish and Wildlife Conservation Commission (LSSC-13-00005). We thank Elizabeth Ford, Stève Desaivre, and technicians from Texas Audubon Society and The Nature Conservancy for assistance collecting samples and conducting observations. Additional field support was provided by Tim and Peggy Wilkinson, Mark Dumesnil, Beau Hardegree, Amanda Hackney, Scott Walter, and John Dindo. Caroline Poli and Ludovic Besaury assisted with sample identification and processing, and Carolyn Wakefield provided administrative assistance in transporting samples. We thank Yoichiro Kanno, Pablo Yorio, Emily Weiser, Beth Ross, Laura Martin, and 2 anonymous reviewers for comments that improved earlier drafts of the manuscript. The South Carolina Cooperative Fish and Wildlife Research Unit is jointly supported by the US Geological Survey, South Carolina DNR, and Clemson University. Any use of trade, firm, or product names is for descriptive purposes only and does not imply endorsement by the US Government.

\section{LITERATURE CITED}

Ahrenholz DW (1991) Population biology and life history of the North American menhadens, Brevoortia spp. Mar Fish Rev 53:3-19

Anderson DW, Gress F, Mais KF, Kelly PR (1980) Brown pelicans as anchovy stock indicators and their relationships to commercial fishing. CCOFI Rep 21:54-61 
Anderson DW, Gress F, Mais KF (1982) Brown pelicans: influence of food supply on reproduction. Oikos 39:23-31

Anthony JA, Roby DD, Turco KR (2000) Lipid content and energy density of forage fishes from the northern Gulf of Alaska. J Exp Mar Biol Ecol 248:53-78

Arthur SC (1919) The emblematic bird of Louisiana. La Hist Q 2:255-256

Ashmole NP (1971) Sea bird ecology and the marine environment. In: Farner DS, King JR (eds) Avian biology, Vol I. Academic Press, New York, p 223-286

Ballance LT, Pitman RL (1999) Foraging ecology of tropical seabirds. In: Adams NJ, Slotow RH (eds) Proc 22 Int Ornithol Congr, Durban, p 2057-2071

* Biasutti M, Sobel AH, Camargo SJ, Creyts TT (2012) Projected changes in the physical climate of the Gulf Coast and Caribbean. Clim Change 112:819-845

Bugge J, Barrett RT, Pedersen T (2011) Optimal foraging in chick-raising Common Guillemots (Uria aalge). J Ornithol 152:253-259

Christmas JY, McBee JT, Waller RS, Sutter FC III (1982) Habitat suitability index models: Gulf menhaden. Report FWS/OBS-82/10.23, US Department of Interior, Fish and Wildlife Service, Washington, D.C.

Cohen LA, Pichegru L, Grémillet D, Coetzee J, Upfold L, Ryan PG (2014) Changes in prey availability impact the foraging behaviour and fitness of Cape gannets over a decade. Mar Ecol Prog Ser 505:281-293

Deegan LA (1990) Effects of estuarine environmental conditions on population dynamics of young-of-the-year gulf menhaden. Mar Ecol Prog Ser 68:195-205

Field DJ, Lin SC, Ben-Zvi M, Goldbogen JA, Shadwick RE (2011) Convergent evolution driven by similar feeding mechanics in balaenopterid whales and pelicans. Anat Rec 294:1273-1282

Fogarty MJ, Nesbitt SA, Gilbert CR (1981) Diet of nestling brown pelicans in Florida. Fla Field Nat 9:38-40

Frederiksen M, Edwards M, Richardson AJ, Halliday NC, Wanless S (2006) From plankton to top predators: bottom-up control of a marine food web across four trophic levels. J Anim Ecol 75:1259-1268

* Golet GH, Kuletz KJ, Roby DD, Irons DB (2000) Adult prey choice affects chick growth and reproductive success in pigeon guillemots. Auk 117:82-91

Green JA, White CR, Bunce A, Frappell PB, Butler PJ (2009) Energetic consequences of plunge diving in gannets. Endang Species Res 10:269-279

KHernquist B, Hjernquist MB (2010) The effects of quantity and quality of prey on population fluctuations in three seabird species. Bird Study 57:19-25

*Houston A (1985) Central-place foraging: some aspects of prey choice for multiple-prey loaders. Am Nat 125: 811-826

* Incardona JP, Gardner LD, Linbo TL, Brown TL and others (2014) Deepwater Horizon crude oil impacts the developing hearts of large predatory pelagic fish. Proc Natl Acad Sci USA 111:E1510-E1518

Jodice PGR, Roby DD, Turco KR, Suryan RM and others (2006) Assessing the nutritional stress hypothesis: relative influence of diet quantity and quality on seabird productivity. Mar Ecol Prog Ser 325:267-279

Jodice PGR, Wickliffe LC, Sachs E (2011) Seabird use of discards from a nearshore shrimp fishery in the South Atlantic Bight, USA. Mar Biol 158:2289-2298

Kadin M, Österblom H, Hentati-Sundberg J, Olsson O (2012) Contrasting effects of food quality and quantity on a marine top predator. Mar Ecol Prog Ser 444:239-249

King KA, Blankinship DR, Payne E, Krynitsky AJ, Hensler GL (1985) Brown pelican populations and pollutants in Texas 1975-1981. Wilson Bull 97:201-214

Love M, Baldera A, Young C, Robbins C (2013) The Gulf of Mexico ecosystem: a coastal and marine atlas. Ocean Conservancy Gulf Restoration Center, New Orleans

MacArthur RH, Pianka ER (1966) On optimal use of a patchy environment. Am Nat 100:603-609

McEachran JD, Fechhelm JD (2010) Fishes of the Gulf of Mexico. University of Texas Press, Austin

* Meynier L, Morel PCH, Mackenzie DDS, Macgibbon A, Chilvers BL, Duignan PJ (2008) Proximate composition, energy content, and fatty acid composition of marine species from Campbell Plateau, New Zealand. NZ J Mar Freshw Res 42:425-437

Muhling BA, Lee SK, Lamkin JT, Liu Y (2011) Predicting the effects of climate change on bluefin tuna (Thunnus thynnus) spawning habitat in the Gulf of Mexico. ICES J Mar Sci 68:1051-1062

Nelson JS (1994) Fishes of the world. John Wiley \& Sons, New York

Orians GH, Pearson NE (1979) On the theory of central place foraging. In: Horn DJ, Mitchell RG, Stairs GR (eds) Analysis of ecological systems. Ohio State University Press, Columbus, p 155-177

\% Österblom H, Olsson O, Blenckner T, Furness RW (2008) Junk-food in marine ecosystems. Oikos 117:967-977

* Payne SA, Johnson BA, Otto RS (1999) Proximate composition of some north-eastern Pacific forage fish species. Fish Oceanogr 8:159-177

* Pinson D, Drummond H (1993) Brown pelican siblicide and the prey-size hypothesis. Behav Ecol Sociobiol 32: 111-118

Romano MD, Piatt JF, Roby DD (2006) Testing the junk-food hypothesis on marine birds: effects of prey type on growth and development. Waterbirds 29:407-414

Kosen DA, Trites AW (2000) Pollock and the decline of Steller sea lions: testing the junk-food hypothesis. Can J Zool 78:1243-1250

Rosen DA, Trites AW (2004) Satiation and compensation for short-term changes in food quality and availability in young Steller sea lions (Eumetopias jubatus). Can J Zool 82:1061-1069

* Sachs EB, Jodice PGR (2009) Behavior of parent and nestling brown pelicans during early brood-rearing. Waterbirds 32:276-281

Sagarese SR, Nuttall MA, Geers TM, Lauretta MV, Walter JF III, Serafy JE (2016) Quantifying the trophic importance of Gulf menhaden within the northern Gulf of Mexico ecosystem. Mar Coast Fish 8:23-45

Schmidt-Nielsen K (ed) (1997) Animal physiology: adaptation and environment, 5th edn. Cambridge University Press, New York

Schreiber RW (1977) Maintenance behavior and communication in the brown pelican. Ornithol Monogr 22:1-78

Shields M (2014) Brown pelican (Pelecanus occidentalis). In: Poole A (ed) The birds of North America. Cornell Laboratory of Ornithology, Ithaca, NY. https://birdsna.org/ Species-Acount/bna/species/brnpel/introduction (accessed 2 January 2016)

Spear LB, Ainley DG (1998) Morphological differences relative to ecological segregation in petrels (Family: Procellariidae) of the Southern Ocean and tropical Pacific. Auk 115:1017-1033 
Spitz J, Mourocq E, Schoen V, Ridoux V (2010) Proximate composition and energy content of forage species from the Bay of Biscay: high- or low-quality food? ICES J Mar Sci 67:909-915

Spitz J, Trites AW, Becquet V, Brind'Amour A, Cherel Y, Galois R, Ridoux V (2012) Cost of living dictates what whales, dolphins and porpoises eat: the importance of prey quality on predator foraging strategies. PLOS ONE 7:e50096

Stickney DG, Torres JJ (1989) Proximate composition and energy content of mesopelagic fishes from the eastern Gulf of Mexico. Mar Biol 103:13-24

Trites AW, Donnelly CP (2003) The decline of Steller sea lions in Alaska: a review of the nutritional stress hypothesis. Mammal Rev 33:3-28

Editorial responsibility: Kyle Elliott,

Sainte-Anne-de-Bellevue, Québec, Canada
*Van Pelt TI, Piatt JF, Lance BK, Roby DD (1997) Proximate composition and energy density of some North Pacific forage fishes. Comp Biochem Physiol A 118: 1393-1398

Vaughan DS, Shertzer KW, Smith JW (2007) Gulf menhaden (Brevoortia patronus) in the US Gulf of Mexico: fishery characteristics and biological reference points for management. Fish Res 83:263-275

*Walter ST, Carloss MR, Hess TJ, Leberg PL (2013) Hurricane, habitat degradation, and land loss effects on brown pelican nesting colonies. J Coast Res 29:187-195

Wilkinson PM, Nesbitt SA, Parnell JF (1994) Recent history and status of the eastern brown pelican. Wildl Soc Bull 22:420-430

Submitted: May 25, 2017; Accepted: August 8, 2017

Proofs received from author(s): October 3, 2017 